\title{
FATHOM
}

\section{Raising Doubts? The Victorian Maternal Ideal and 'Unnatural' Mothers in Thomas Hardy's Short Stories}

L'idéal maternel victorien et les figures de mères indignes dans les nouvelles de Thomas Hardy

\section{Oindrila Ghosh}

\section{OpenEdition}

\section{Journals}

\section{Electronic version}

URL: http://journals.openedition.org/fathom/517

DOI: $10.4000 /$ fathom.517

ISSN: 2270-6798

\section{Publisher}

Association française sur les études sur Thomas Hardy

\section{Electronic reference}

Oindrila Ghosh, « Raising Doubts? The Victorian Maternal Ideal and 'Unnatural' Mothers in Thomas Hardy's Short Stories », FATHOM [Online], 3 | 2016, Online since 30 April 2016, connection on 20 April 2019. URL : http://journals.openedition.org/fathom/517 ; DOI : 10.4000/fathom.517 


\title{
Raising Doubts? The Victorian Maternal Ideal and 'Unnatural' Mothers in Thomas Hardy's Short Stories
}

\author{
L'idéal maternel victorien et les figures de mères indignes dans les nouvelles de \\ Thomas Hardy
}

Oindrila Ghosh

“I don't know how I felt about the baby. I seemed

to hate it - it was like a heavy weight hanging round my neck" (Eliot 453)

"I hated the thought of having children [...] and have no adoration for very little babies (particularly not in their baths till they are past 3 or 4 months)" (Fulford 165)

The two epigraphs, one from Adam Bede and the other from one of Queen Victoria's letters to her eldest daughter the Princess Royal, strike the keynote to the argument contained in this essay. "Unnatural" - i.e. deviating from the expectations and generalizations of society - mothers were present in the very matrix of Victorian age and society, which assiduously built up the socially acceptable ideal of selfless motherhood according to which women, once they became mothers, were expected to forget their own needs as humans. The word "unnatural" is used here to refer to the repulsion for babies, expressed in the second epigraph, from the pen of the otherwise exemplary symbol of the devoted wife and doting mother, so deeply etched in the Victorian social psyche. In Eliot's novel Adam Bede, Hetty's abandonment of her baby may shock the reader. However what remains crucial, but often ignored, is the question: under what compulsions did Hetty abandon it? 
Rhoda Brook, the rejected mistress of Farmer Lodge in Thomas Hardy's "A Withered Arm" (Hardy 1988), occupies a singular position in the entire gamut of Hardy's short stories. From the beginning she is depicted as a mysterious woman: "a thin fading woman of thirty milked somewhat apart from the rest" (Hardy 1988, 52). What has passed between Rhoda and Lodge is never mentioned, but we are told: “[he] ha'n't spoke to Rhoda Brook for years" (53). That she was once his mistress, whom he had used sexually and emotionally, is clear; but he seems to have chosen to sever all ties with her eventually. Even the illegitimate child that resulted from his union with Rhoda is ignored by him. A victim of brusque abandonment by Lodge, burdened with unwelcome motherhood and forced to choose a life of aloofness in order to escape the jeers of the villagers, Rhoda vents her harshness on her child and later directs her jealousy towards Lodge's beautiful young wife Gertrude. Rhoda's difficult life as discarded mistress and unwed mother had hardened her so much that her natural impulses are completely frozen, and even motherhood is unable to soften her. Being an unwelcome responsibility, Rhoda's relationship with her child is devoid of warmth and affection and is very uncomfortable. She uses her boy as an instrument to escalate her sexual rivalry with Gertrude. This nonchalance and coldness towards her son in Rhoda is vital to the understanding of the complex psychology underlying the maternal instinct within her.

Social pressure, physical discomfort, emotional unfulfilment are the root cause of a woman's victimization; and a victimized woman can rarely be expected to become a "good" mother. It is an aspect which Thomas Hardy brings out subtly, time and again, but with great emphasis and empathy, in his novels, poems and short stories. In fact, Hardy's world is full of women who feel that they are the victims of a cruel destiny and are trapped in a world which is too petty to appreciate their real worth. Such views are expressed by a prominent character in his short stories, Ella Marchmill, the heroine of “An Imaginative Woman" from the collection Life's Little Ironies (Hardy 1988). She too feels trapped, unsatisfied and utterly unappreciated in a prosaic marriage with a gun maker (suggesting destruction as opposed to Ella's love for creation through poetry). Ella is not physically ill treated; Hardy never gives us the slightest hint that Marchmill has not provided his wife and children with the choicest amenities of life; in fact they are affluent enough to go on a luxurious holiday. What then is the cause of her unhappiness? There could be only one reason: the lack of appreciation and of encouragement from a husband whose trade is detrimental to, in fact the very opposite of, her creative temperament. Ella, we learn, is a poet. Thus, her infatuation for the poet Robert Trewe is not sexual but rather emotional or psychological. Martin Ray has highlighted, in his textual study of the short stories, Hardy's intention of emphasizing the spiritual nature of Ella's attraction for Trewe. Ray thus comments regarding Hardy's authorial intentions:

The other blue-ink alterations all occur on fos. 16-18, in the scene portraying Ella in bed with Trewe's photograph. The first is a reference to her feeling that she is 'permeated by him' (Trewe), which Hardy revised to 'permeated by his spirit', a more ethereal and arguably less physical form of possession (Ray 178).

It can be argued that the textual change was intended not just to tone down a sexual connection which would be unacceptable to the Victorian reading public, but also to highlight the spiritual bonding between the two poetic temperaments. Ella's misery presumably lies in her being forced to live with, and bear children to, a husband who offends her fine sensibilities. All she craves for is the assurance of being understood and appreciated. 
5 This unhappiness, this emotional unfulfilment, is important in understanding Ella's personality as a mother too. It is easy to describe her as an "unnatural" mother because of the way she treats her children - a way which does not stick to the Victorian maternal ideal in any way. Ella is decidedly unhappy in her marriage and her being the mother of three children never seems to seep deep into her or affect her. When the chance of meeting Robert Trewe is lost to her, her misery is so profound that the narrator comments that even her children fail to provide her with any comfort: "When the children came in with wet stockings, and ran up to her to tell her of their adventures, she could not feel she cared about them half as much as usual" (Hardy 1988, 387).

Not once in the story do we find Ella loving her children in the socially-labelledas-"natural" way and the only time she does so, it is to dissipate her sense of disappointment and misery by "unnecessarily kissing the children" (Hardy 1988, 395) and even then she is immediately repulsed as she associates them with her union with a "plain-looking" gun maker: she has sudden bouts of "disgust at being reminded how plain-looking they were, like their father" (395). That her marital unhappiness, her dissatisfaction with life with an unsuited partner, deeply affects Ella's maternal instincts is clear at every step in the story. Motherhood, which was then conventionally depicted as the supreme fulfilment of a woman's life, seems to have left Ella unstirred and Hardy's narrator in no way critical of his heroine who deviates from the Victorian norm. Motherhood has neither compensated the emotional void of Ella's married life, nor evoked in her the sense of sacrifice, or unconditional and constant love, or selflessness, the very traits by which Victorian mothers were estimated. When Ella goes to attend Trewe's funeral she has not only forgotten that she has a husband but also that she is the mother "of three children and a fourth coming" (399). This is indisputably "unnatural" when measured by the yardstick of Victorian notions of motherhood. Shanta Dutta insightfully comments that "[1]ater, when she [Ella] is expecting her fourth child, she must have often wished (like Edith), when she gazed at the poet's picture, that the coming child was the 'handsome' Trewe's rather than the 'plain-looking' Marchmill's" (Dutta 98).

7 The fulfilment of Ella's unconscious wish is perhaps reflected in the "dreamy" expression of the poet and the colour of his hair which is mirrored on her son's face. However, what is of importance is the fact that Ella's deathbed confession inadvertently sows into her husband's mind suspicions about her non-existent relationship with the dead poet. It affects the innocent and blameless boy and deprives him of legitimate paternal affection. When Sophie Gilmartin and Rod Mengham are critical of such maternal/parental irresponsibility, they are perhaps also registering the ambivalence present within the Victorian social matrix - with large families, limited birth control at the disposal of women and also the restricted choices they had regarding the bearing of children - of the latent resentment towards repeated maternity. They comment:

When she lies dying in the aftermath of giving birth to her fourth child, it is unclear whether the ascription of "unnecessary life" to the infant is a mark of her own resentfulness or of the narrator's disillusionment. Either way, the dismissal of children themselves, and of the attention paid to them as "unnecessary" mounts a direct challenge to the reader's ethical judgement. (Gilmartin \& Mengham 115; my italics)

8 The quoted phrase reveals the recurrent and recognizable pattern in Hardy's short stories and novels, of women expressing their disinclination (as of Sue Bridehead who thinks it is an audacious act to bring children into the world) or resentment at bearing children; and probably also Hardy's own sardonic views on birth and life in general. Such 
a step, if not deliberately but accidentally jeopardizing the life of a new-born, is taken in yet another short story by Sir Petrick's Lady, in the eponymous story from A Group of Noble Dames (Hardy 1988), when she confesses to her husband about her adultery (which is the result of a mental delusion) with the heir of a socially superior aristocratic family. In this case, however, the woman's husband is not outraged at being cuckolded but, rather, exultant at his wife's noble enterprise to improve the common and weak traits of his family lineage by aristocratic biological grafting. However, this case is similar to that in the story discussed earlier because the lady, eager to divulge her imaginary "crime" of adultery, on her deathbed, leaves her new-born liable to be cast off from paternal affections. It is just by sheer good fortune that Sir Petrick, instead of casting off the child as a proof of adultery, brings it up with affection.

9 At the end of Ella's story, the reader is left with a mixed feeling of pity for a woman who was meant for higher things and deserved a "fuller appreciator", but probably also with a sense of annoyance for a heedless mother who could leave her new-born insecure, out of her own feeling of unfounded guilt; but the narrator's neutrality is striking and cannot be ignored while forming an opinion of Ella. Hardy's handling of Ella's story provides us with deep psychological insight into the female mind and also reveals how deeply Hardy sympathized with the lot of women. No kind of oppression - be it social, parental, emotional, or psychological - that affected women ever escaped his notice or his deep sympathy. Ella's indifference and Hetty's cruelty can both be explained, partially, as the outcome of the deep-seated grudge against their children as the symbols of patriarchal restrictions which impede a woman from living her life in her own terms. Shulamith Firestone, the radical feminist, has something very significant to say on this:

We must include the oppression of children in any program for feminist revolution

[...]. The mother who wants to kill her child for what she has had to sacrifice for it

(a common desire) learns to love that same child only when she understands that it

is as helpless, as oppressed as she is, and by the same oppressor: then her hatred is

directed outward, and "motherlove" is born (Firestone 118).

Thus, though one may feel that "An Imaginative Woman" holds a unique place in the entire corpus of Hardy's short stories as an instance of maternal neglect, Hardy remains noticeably non-judgmental and neutral. The narrative leaves enough scope for the reader to make value judgements where Ella turns to an ethereal love and is indifferent towards her children. Sophie Gilmartin and Rod Mengham comment that "[u]ntil the very end, the children are barely noticed; they are never individualised, but are referred to sweepingly in formulations expressive of Ella's boredom at the prospect of motherhood, which to her is one of the root causes of her emotional stagnation" (Gilmartin \& Mengham 114). The stagnation resulting from the gloom at being just a "multiplier of her kind", whereby the indifference towards the children gradually transforms into negligence, is evident from Ella's lack of alacrity to get the children out of their wet stockings when they come home from the beach. Thus, as a poet, Ella who is eager to give birth to the "nurslings of immortality", actually turns her back on real, living and breathing children (Gilmartin \& Mengham 114).

11 Hardy was far in advance of his time, in every sense, in his philosophy as also in his psychological understanding of the human mind. What he had handled with ease clearly a century ago in "An Imaginative Woman" is formulated in a clear, theoretical and clinical study much later in a twentieth century work by Ann Dally. Dally says that a woman with an unsatisfying or difficult marriage may either turn her child into a "confidante", the 
disastrous results of which we see in Sue's relations with Little Father Time in Jude the Obscure, or there are others yet - like Ella - who

use their children as instruments to enhance themselves. If they are very immature they regard their children as toys, to be played with, picked up and dropt, put away and ignored according to the feelings of the moment. The child is bewildered and confused. One moment he is loved and the centre of attention. The next minute his mother appears to have forgotten him and is pursuing some other interest (Dally 107).

Thus, through Ella Marchmill's case, Hardy was exploring a mental state that came to be clinically recognized and spoken about only a century later. The above passage from Dally clearly recognizes and defines the tendency in a mother to treat the child/children to suit her moods or needs (Dally 87), as is seen in Ella's sudden bouts of disgust for, and sudden effusions of showering affection on, her children and at other times of her complete obliviousness to them. The constant reminder that they resemble their gun-maker father and do not share her artistic temperament, nor her refinement, may have been the outcome of her subconscious feeling that her children did not bring her the same social prestige which the mother of potentially talented children would get in society. This probably accounts for Ella's unpredictable and moody behaviour with her children. This goes on to show how Hardy was much ahead of his time in his intuitive understanding of human psychology in particular, and life in general. Thus a woman who would have come under moral censure from contemporary Victorian readers was treated by Hardy with a deep psychological insight, free from judgment.

Although unique in their portrayal, some of Hardy's female characters in the short stories may be categorized under the same apparent syndrome of "unnaturalness" towards their offspring. Like Ella, Car'line, in “The Fiddler of the Reels” (Life's Little Ironies, Hardy 1988) is another woman whose status as mother and as victim is coherent. Car'line is the victim of the fiendish Mop Ollamoor's uncanny power of music. The narrative voice tells us that Mop has a "weird and wizardly" power over "unsophisticated maidenhood". Mop takes advantage of Car'line through the uncanny use of his "satanic" fiddle, leaving her an unwed mother. That a sense of responsibility has not come to her with age and, as expected from society, from motherhood is evident from the power that Ollamoor is capable of exerting over her even long years after his actual seduction of her: "The saltatory tendency which the fiddler and his cunning instrument had ever been able to start in her was seizing Car'line just as it had done in earlier years. [...] Tired as she was, she grasped her little girl by the hand, and plunging in at the bottom of the figure, whirled about with the rest" (Hardy 1988, 505). What Hardy keeps silent on, owing to the prudery of the Victorian reading public, is that Mop's "acoustic magnetism" is interlinked with his sexual attractiveness, of which Car'line is a slavish victim and the narrator states this in so many words: "There was that in the look of Mop's one eye which said: 'you cannot leave off, dear, whether you would or no!" (507). And a little further: "[s]he thus continued to dance alone, defiantly as she thought, but in truth slavishly and abjectly, subject to every wave of the melody, and probed by the gimlet-like gaze of her fascinator's eye" (507). Elsewhere in the story, the use of the terms "hysteric", "aggressively tweedling", "seductive strains", “weak", “overpowered", "excruciating spasms", "blissful torture" shows it is clearly a sexual battle that is going on between Mop and Car'line, and a battle that is unequal, with the latter reduced to a victim being tortured, manipulated and enslaved by a man who relishes his abnormal grip over her. Till such a point perhaps Car'line easily holds the sympathy of the Victorian reader, who 
realizes her helplessness in the face of Mop's quite uncanny, preternatural powers. Shanta Dutta thus points out: "In her unnaturalness as a mother Car'line forfeits the sympathy that she deserves as a woman victimized" (Dutta 99). This might have been true in the context of Victorian views, although it would probably not fit present criteria, as we would not deny sympathy to a woman merely on such grounds. Car'line loses her child through a series of events ending with her inability to resist her sexual weakness - for which Hardy at least does not hold her as guilty nor indict her, nor leaves any clue for the reader to do so, revealing thus his moral bearings to be untouched by rigid Victorian formulations. However, later on in the narrative, what probably strikes one is her "unnaturalness" when she remains nonchalant and unperturbed when her little girl is abducted. Hardy holds out Ned's paternal anxiety as a foil to Car'line's lack of concern. At losing Carry, Ned is frantic: “But she is mine, all the same! Ha'n't I nussed her? Ha'n't I fed her and teached her? Ha'n't I played wi' her? O, little Carry - gone with that rogue gone!" (Hardy 1988, 509). Meanwhile, Car'line remains strikingly calm and foolishly trusting about her daughter's fate at the hands of a man whom she, of all people, has the least reason to trust. She chides the anxious Ned: "Don't 'ee raft yourself so Ned! You prevent my getting a bit o' rest!" (509). This is cold in contrast to the man's love and anxiety for the child who is not even his natural or biological offspring.

But, striking as it is in terms of Victorian morality, the narrator never condemns Car'line for her callousness. There is neither covert nor explicit censure for her unconcern. There could be a possible explanation in that albeit silently, Hardy was sympathetic even towards Car'line probably because he saw her as a woman who had not yet attained maturity. Her maternity has been a mere biological event and the narrator thus feels incapable of passing a severe sentence on a woman who is herself a child in terms of her mental growth and development. She is incapable of even gauging the enormity of her loss. Car'line's child-like status is pinpointed in the story when she comes to Ned's lodgings with her child. Ned's attitude to her is a repetition of his attitude towards the child. He assumes a paternal role towards both of them: "The readymade household of which he suddenly found himself the head imparted a cosy aspect to his room, and a paternal one to himself. Presently he turned to the child and kissed now blooming cheeks: and, looking wistfully at Car'line, kissed her also" (Hardy 1988, 503).

Motherhood, as we have seen, was generally believed then to soften a woman and unleash her hidden stores of love, protectiveness and selflessness. This was nothing but yet another generalization that society had erected and seeks to perpetuate for its own benefit. That all women did not satisfy this expected prerequisite for motherhood can be recognized from the aforementioned stories but more so even from Maria i.e. Lady Icenway's attitude towards her own motherhood in the eponymous story from Life's Little Ironies (Hardy 1988). A victim of Anderling's bigamous deception, she rejects him totally and cuts off every link with him. Thus far we are able to retain our sympathy for her as a victim of male betrayal. But Maria does not sit back or pine away at her betrayal; she too carries out a deception to secure for herself a title and the position of Lord Icenway's wife. Her little boy (born from her first liaison) is never mentioned in the story as anything else but a mere appendage, a relic of her brief union with the foreigner Anderling. Maria starts losing our sympathy as she ill-treats the repentant, broken Anderling. She uses her child, her powers and rights of motherhood, to torment Anderling. Motherhood is not a fulfilling, uplifting or ennobling experience for her, but rather it is like a dangerous weapon in the hands of a headstrong and irresponsible child. 
She is a hard-hearted, self-seeking and relentless woman who does not know how to forgive.

It is thus not shocking, nor surprising, to see Maria trying to use not only Anderling but also motherhood as an instrument to hold her place and position in Lord Icenway's heart and good books. Seeing her husband's growing displeasure at her inability to give him an heir, she hits upon a cunning idea. She wishes to utilize her former husband, who has been forced to take up menial service as a gardener (out of paternal affection), to get impregnated, thus satisfying Lord Icenway's desire of fathering a child. Her deceptive temperament and cunning opportunism stun us. Hardy dares to depict Maria as a woman not ennobled by motherhood, as Victorian social ethos would expect. Her "unnaturalness" as a mother is highlighted by romanticizing the father's affection for his little boy. Yet, we once again notice the lack of any narratorial censure. This is again probably because Hardy retained full sympathy for Maria, despite her scheming and deception. In a male-dominated society the only prestige or position of respect that women could win from their husbands, at least theoretically, was through begetting male heirs for them. The kind of social pressure that women felt with regard to motherhood in those times - as they feel even now in the twenty-first century in some cultures - when their worth or usefulness was equated with producing children, is something that we can only try to imagine. Hardy's sympathetic vision exonerates Maria, despite her deceptions, probably because he looks upon her as a victim. However, Hardy's sense of fair play is also operative in the story because he does not side with Maria's ill treatment of Anderling. In fact the sad, repentant, emaciated father of Maria's little boy is transformed into such an object of sympathy that we are willing to forgive him his initial offence towards Maria. It is however relevant at this point to express that Hardy's attitude towards women is neither that of a misogynist nor that of an idealist, but quite a balanced point of view, and essentially one where women are presented as bundles of contradictions, and therefore actually credible.

17 Another example of such complex behaviour may be found in the story "To Please His Wife" (Life's Little Ironies, Hardy 1988). There, Hardy focuses on the mother and the wife from a different angle and aspect. Joanna, from the very inception of the story, is depicted as a woman who is self-seeking and destructive by nature. Her marriage to Shadrach is the outcome not of sincere love but of her jealousy towards Emily, to whom Shadrach had been initially betrothed, and also of her sheer covetousness. However, when Joanna becomes the mother of two beautiful sons, the love that was never lavished on Shadrach goes out towards them so that the narrator says: "Two sons were born to them, whom their mother loved to idolatry, although she had never passionately loved her husband; and she lavished upon them all her forethought and care" (Hardy 1988, 484). This is an interesting description of Joanna's passionate mother-love and it acts as a foil to the monstrous change in her when she acquiesces in sending her sons out to sea in order to get rich in the shortest possible time. Her husband's returns from sea voyages, though a fortune in itself, is not enough to satisfy her and she laments that "her boys will have to live by steering the ships that the Lesters own" (488). She fights a battle with her maternal anxiety regarding the dangers of the sea but finally when she assents to the voyage, with her sons accompanying their father, it is done in sheer foolish egotism:

The idea grew and magnified, and the mother's heart was crushed and stifled by it. Emmy was growing too patronizing; it could not be borne. Shadrach's wife could not help nagging him about their comparative poverty. The young men, amiable as their father, when spoken to on the subject of a voyage of enterprise, were willing to 
embark. [...] Everything now hung upon their mother's assent. She withheld it long, but at last gave the word [...]. (Hardy 1988, 489; my italics) at work here in Joanna despite her immense love for her sons. The belief that three men instead of one would increase the prospect of profit, and hence the prospect of outdoing Emily, makes Joanna ignore her fears for the well-being of her young sons. The joy of being able to spite Emily is such that at one moment the "good-bye, mother!" chalked by her sons, on the bureau before they left for the voyage, makes her burst into tears and at the very next moment a look at Emily's house makes her face light up with "a gleam of triumph" at the anticipation of being "released from the thraldom of subservience" (Hardy 1988, 490). In the conclusion to the story Hardy

dispassionately presents the decrepit woman's suffering. The detached narrator simply and objectively depicts the pitiable lot that Joanna's jealousy, envy, and hatred have brought her - just stark reality which underscores her agonizing condition [...]. Hardy's objectivity evokes the reader's sympathy for the poor deluded woman (Beavers 245).

thus, Hardy remains uncritical. As a handsome woman with a relatively humble background and no means to reach a position of affluence other than marriage, the intrinsically ambitious Joanna gradually degenerates into a jealous and covetous woman for whom wealth and a life of comfort for herself and her sons assumes greater importance than having her sons safe at home with her. As Kristin Brady writes: "as a personification of ambition, she [Joanna] comes to her deserved end, but as a woman she is the object only of pity" (Brady 132); and it is this emotion that Hardy wishes to elicit for Joanna from his readers. As a mother, Joanna's unnatural ambition, jealousy and pursuit of "a carriage and pair" (Hardy 1988, 488) cost her her sons' lives and she realizes the irrevocable nature of her actions only after she has thoughtlessly squandered her real wealth. Hardy's narrator assumes not the conventional voice indicting her, suggesting a punishment richly deserved, but that of the compassionate father-figure whose lovingkindness encompasses even such a woman whom the rest of humanity strikes off as being beyond the pale of human sympathy.

This "monstrosity", "selfishness" or "unnaturalness" in mothers which Hardy depicts without judgment in his short stories, is neither new nor unique. It was also treated in both his own novels as well as in the works of other writers of the nineteenth century. As previously mentioned, one may find it in George Eliot's Adam Bede, where Hetty Sorrel abandons her new-born; but it appears also for example in Dickens's Bleak House where Mrs. Jellyby shirks all the responsibilities of her household and her brood of children and sets about organizing some charity mission to Boorrioboola-Gha; and it also features, as we shall see later in further detail, in Hardy's own Jude the Obscure with Arabella's cruel indifference to her own child, Little Father Time. What then is unique in Hardy's short stories is the deep, penetrative insight with which he probes into the reasons behind such "unnatural" behaviour by Victorian standards. What is unquestionable is the fact that each of the women spoken about in this essay - and a few others like Lady Caroline ("The Marchioness of Stonehenge") and Rhoda ("The Withered Arm") - are "imperfect" mothers who are "unnatural" in their treatment towards their children but Hardy shows, not overtly but subtly through the sub-text of his stories, that each one of them is a victim of either social, marital, sexual or emotional repression, the result of which being their mental unfitness, emotional unpreparedness, or else temperamental unsuitability for motherhood. It is therefore not only improper but also unfair to expect from such 
women the "conventional" sentiments associated with motherhood, nor should we believe after Victorian conduct books that motherhood will recompense them for all the deprivation, repression or betrayal that they have faced at the hands of patriarchal society.

It is perhaps this understanding that prevents Hardy from pronouncing any harsh sentence upon these women. Like many contemporary women writers, he seems to agree and sympathize with the truth that not every woman's fulfilment of a biological urge to procreate is followed by an impulse to nurture. We see him voice such sentiments through Ella Marchmill and the idea finds its echo in the work of nineteenth-century American writer Kate Chopin, whose heroine Edna Pontellier, in The Awakening, wishes to lead an independent life away from her children but, unable to shake off the mantle of society-enforced attachment to them, is compelled to commit suicide rather than embrace the life-long commitment to them. At one point in the story Edna makes a striking comment: "I would give up the unessential; I would give up my money, I would give my life for my children; but I wouldn't give myself. I can't make it more clear; it's something which I am beginning to comprehend, which is revealing itself to me" (Chopin 90). Edna strikes the keynote to what most twentieth-century feminists strove to point out - that motherhood is just one stage of a woman's life, not its entirety, neither does being a mother mean the end of being a woman or, for that matter, being human, with the basic need for self-fulfilment. Neither Edna's love for the sensuous side of life nor Ella's passion for poetry comes in the way of their being mothers, or feeling love for their children. They appear "unnatural" only because society, especially nineteenth-century English and American societies, expected women to live a life of self-denial, of austere self-sacrifice once they became mothers. Hardy's heroines remain strikingly individual, imperfect and human even after they have experienced motherhood.

Undoubtedly, motherhood was the single most important way to raise women to a position of power, prestige and veneration in Victorian England and many women spent miserable lives trying to emulate such a role praised by philosophers and conduct book writers, but social documents of the period reveal the true picture where mothers were always not-so-ideal, at times even reluctant to become "mothers":

Many women, however, clearly resisted childbearing: by sharing contraceptive information, by cooperating with their sexual partners in preventive measures, by abortion, by infanticide, and by deliberate neglect of the infant. Such women had pressing reasons to avoid motherhood. Many working women knew that they could not support another child, and that their own labours in factories and fields would leave them little time for the joys of motherhood. Mothers of illegitimate babies faced dishonour and economic hardship; in England many could support themselves only as live-in wet nurses, so that their own babies often died of malnutrition and disease. But even an economically secure married woman sometimes decided to avoid or terminate pregnancy when her own health was at risk or when another child would be inconvenient. (Hellerstein \& al. 128)

"Unnatural" mothers were present in the very social matrix that gave birth to, fed and nurtured the myth of the ideal mother - one who, irrespective of her social, economic, physiological or psychological condition, would supposedly embrace her role of a mother with absolute ecstasy. In Hellerstein, Parker Hume and Offen's Victorian Women, a resourceful compilation of Victorian documents related to the role and position of women, we come across authentic documents related to a very inhuman and surreptitious practice prevalent in the society of the time, that of baby farming. Unwed mothers surreptitiously gave away their new born to be taken care of in exchange for 
money, away from the glaring Victorian moral-policing, but the infants often died owing to lack of nutrition or were deliberately murdered by the baby farmers (Hellerstein \& al. 238). As the dark underbelly of the illuminated pictures and panegyrics of motherhood, these baby farms remained as sad blemishes on the picture of a society riddled with "fallen women", prostitutes, unwed mothers, and illegitimate children who were sought to be disposed of in any possible way.

In such a Victorian social milieu, not only is Hardy not critical of his female characters for retaining their selfhood, he at times tries to explore their unfulfilled emotional needs or tries to relate their behaviour to their victimization by a society that denies them any opportunity for growth. At other times Hardy openly sympathizes with them even when they are on the very brink of losing the readers' sympathies. Hardy is successful in making the point that motherhood is not a biological state like maternity but rather a mental/emotional state. As Dorothy Dinnerstein rightly argues:

What makes motherhood reliable is that the erotic flow between the child and its female parent is primed by a set of powerful post-partum mechanisms, mechanisms which prompt not only women but also simpler she-mammals, to nurture and protect their young. What makes motherhood monstrous, atomistic, is that we force these primitive biological underpinnings - which are neither specifically human nor designed to do more than guarantee the brute survival of the newbornto carry a peculiarly human, and wildly disproportionate psychological weight (Dinnerstein 77-78).

Hardy does not appear to be critical of his "unnatural" heroines because he does not put this "psychological weight" on them and regards them as humanly imperfect despite the social tendency to elevate mothers and motherhood to a pedestal of unfaltering sacredness and infallibility. His heroines are neither more nor less "unnatural" than Ibsen's Nora who slammed the door at her husband and child as a way of asserting her selfhood.

This brings us back to our initial question: what was the reason then that made those women physically or emotionally abandon their children, or deprive them of any "normal" maternal love? The cause then, that comes up first and foremost among other causes, in all of Victorian fiction as in Hardy's novels and stories, is the social cause - the fear of the stigma of unwelcome motherhood. A glance at the matrix of society and at its laws invariably in favour of men, will reveal the reasons of that apparent female heartlessness. A good instance of such double standards is The New Poor Law of 1834 which was clearly marked by the typical Victorian sexual bias and, in the case of physical abuse, was very partial to the offending male who, according to the Commissioners, did not deserve further punishment - nor did the woman deserve wholesale sympathy. Hardy's poems, stories and novels too abound in depictions of the plight of fallen women or ruined maids, and we may see for example in the poem "A Sunday Morning Tragedy" (Hardy 2001, 201-205) his poignant portrayal of female suffering. In this piece Hardy presents a critical situation where the narrator, who is a mother, tells the pitiable tale of her young daughter caught in the snare of unwed pregnancy. As a mother she is helpless and she has to choose between her daughter's life and the risk of jeopardizing it through an unsafe attempt at abortion in order to prevent the girl's loss of reputation through "ill-mothering". That Hardy was extremely sensitive towards such issues where young women drifted towards unwed motherhood and lost their young lives just to save face can be understood from these lines: 
He pulled from underneath his smock

The herb I sought, my curse to be -

"At times I use it in my flock,"

He said, and hope waxed strong in me.

“'Tis meant to balk ill-motherings' -

(Ill-motherings! Why should they be?) -

"If not, would God have sent such things?"

So spoke the shepherd unto me. (Hardy 2001, 203; my italics) be?" - which may be read as two questions at once: first, why should such events of untoward pregnancies happen to girls who are deliberately kept in the dark about the biological processes of their bodies and thus fall prey to the dangers inherent in the natural laws of attraction? And second, why should society dub these biological occurrences as "ill" only because they are not in keeping with the norms of society? These unvoiced questions direct our attention to the narrator who, as Hardy's mouthpiece, wrote again and again, with empathy, about the young women who suffered such "ill-motherings" - Fanny Robin, Tess, Viviette, Lady Caroline, Anna ("On the Western Circuit", Life's Little Ironies) - and indicated how their actions were always framed, first and foremost, by the menace of social stigma.

Any discussion on Hardy's depiction of "unnatural mothers" would be incomplete without mentioning Arabella in Jude the Obscure. Arabella is perhaps the only woman who forfeited Hardy's wide and unstinted empathy for women. She has been delineated as a creature with mere animalistic drives, typical of the struggle for existence in the state of nature that was confronting the Victorian mind through the works of Darwin and Spencer. Arabella entraps Jude into an unequal marriage, dooming his prospects in life, and she later gives birth to their child, only to send him away to Jude in order to enjoy her life free from encumbrance. Her cruelty, her callousness as a mother and her libidinous nature, are revolting to us and Hardy meant it to be so. Unlike the ruined maid in "A Sunday Morning Tragedy", Arabella does not resort to a quack's herbs for abortion to save face, but she will later use the aid of physician-paramour Vilbert to protect herself from unwanted pregnancies from her numerous affairs.

With the characters of Arabella, Sue, and Little Father Time, Jude the Obscure offers an illustration of Hardy's vision of the mother/child relationship as a sense of victimization and disillusionment both for the mother and the child. And indeed one might note that in the entire corpus of Hardy's fiction there is a dearth of children. Wessex remains the backdrop of adult tragedy, and rare are the descriptions of childhood. Children are born, illegitimately or prematurely, to fallen women, only to die even before the budding of their lives. This probably had much to do with Hardy's vision of life as a sea of sorrow where, given a choice, man had better not choose to be born, as Little Father Time himself voices it.

In the Victorian society, fear and force made many women both unprepared for and unable to cope with their new role as mothers. The harshness of that forced or unwanted condition is revealed by the stark contrast between the image of motherhood as portrayed in the conduct books of the times and the reality of the situation as experienced by mothers. The feelings were often contrary to what the manuals assumed them to be, as is evident in the letters of Queen Victoria, who was projected as the role model for maternal attributes, but whose actual views on motherhood might actually 
have placed her into the category of "unnatural mothers". This is what Natalie MacKnight summarizes:

Second only to the Virgin Mother in her influence on Victorian expectations of motherhood was Queen Victoria. As a mother of nine, and as the sovereign of England, she became an emblem of the ideal mother - fertile; patient; longsuffering in her labours; devoted to her husband, children, and country; and very traditional in her public attitudes about the role of men and women. Her 'iron will' helped her to keep up her ideal image in spite of the reality of her feelings toward sex, pregnancy and motherhood. Queen Victoria perpetuated the gap between the ideal and the real that conduct books for mothers had developed. The public perceived her as strong, contented mother, but in private Victoria actually expressed startlingly negative sentiments about motherhood [...]. For the queen, sex and labour were the heaviest crosses of women's martyrdom [...]; in effect, the queen's very understandable, realistic feelings about motherhood are so far from the accepted ideal of the time that they would place her in the ranks of the villains in the novelistic world (MacKnight 14-16).

Thus, if the Queen, the figure at the pivot of Victorian society and morals, was honestly repulsed by the incessant production of babies and described in her letters to her daughters the miseries of marriage and motherhood, and was so vocal about the horrors of childbirth and her dislike of children, then it is little wonder that ordinary women naturally felt the same repulsion, or at least ambivalence faced with greater tribulations in life. This clearly exposes the sham portrayal of mothers in Victorian fiction, since mothers depicted as "unnatural" villains are actually responding to a role thrust upon them as an unfair burden. Such instances of women chafing at forcible maternity, and failing more often than not to perform the role according to the social ideals, remain at the centre of Hardy's fiction, especially his short stories.

Hardy portrays mothers with all their imperfections as women and he highlights the (often-ignored) fact that women do not cease to be human beings once they become mothers. While there is silent disapproval for the harshness that these women show towards their children, there is absence of any severe condemnation for them because they are already victimized and disabled by a society operating on the principles of sexual double-standards and lack of opportunities for the so-called "weaker sex".

\section{BIBLIOGRAPHY}

Beavers, Myrtle B., "Studies towards a Critical Approach to Thomas Hardy's Life's Little Ironies", unpublished PhD Diss., The Florida University, 1994.

Brady, Kristin, The Short Stories of Thomas Hardy, London: Macmillan, 1982.

Chopin, Kate, The Awakening, London: David Campbell, 1992.

Dally, Ann, Mothers: Their Power and Influence, London: Weidenfield and Nicholson, 1976.

Dinnerstein, Dorothy, The Rocking of the Cradle and the Ruling of the World, New York: Harper \& Row, 1976. 
Dutta, Shanta, Ambivalence in Hardy: A Study of His Attitude to Women, London: Macmillan, 2000.

Eliot, George, Adam Bede, Oxford: OUP, 1996.

Firestone, Shulamith, The Dialectic of Sex: The Case of Feminist Revolution, London: Paladin, 1972.

Fulford, Roger ed., Dearest Child: Letters Between Queen Victoria and the Princess Royal 1858-1861, New York: Holt, Rhinehart \& Winston, 1965.

Gilmartin, Sophie \& Rod Mengham, Thomas Hardy's Shorter Fiction: a Critical Study, Edinburgh: Edinburgh UP, 2007.

Hardy, Thomas, Jude the Obscure (1895), London: Macmillan (The New Wessex Edition), 1974.

Hardy, Thomas, The Collected Short Stories of Thomas Hardy, ed. Desmond Hawkins, London: Macmillan (The New Wessex Edition), 1988.

Hardy, Thomas, The Complete Poems, ed. James Gibson, Basingstoke: Palgrave, 2001.

Hellerstein, Erna O., Leslie P. Hume, Karen M. Offen, eds., Victorian Women: a Documentary Account of Women's Lives in Nineteenth Century England, France and the United States, Brighton, Sussex: The Harvester Press, 1981.

MacKnight, Natalie J., Suffering Mothers in Mid-Victorian Fiction, London: Macmillan, 1997.

Ray, Martin, Thomas Hardy: A Textual Study of the Short Stories, Aldershot: Ashgate, 1997.

\section{ABSTRACTS}

Thomas Hardy was a Victorian by birth and chronology, but in his understanding of women and creation of strong female characters he might be considered as a precursor of feminist thought. His short stories act as contrapuntal to his novels in their preoccupation with women and their tribulations often as 'unwed' mothers. In them however, motherhood, in its many shades, is brought out from the peripheries of the plot to the very centre, treating each episode as a unique case study and thereby studying women as individuals not typecast reductions as Victorian society and literature was habituated to do. Social pressure, physical discomfort, emotional unfulfilment are the root cause of a woman's victimization; and a victimized woman can rarely be expected to become a "good", let alone "perfect", mother. This essay would like to inspect how some of Hardy's short stories raise doubts upon the concept of the "perfect" woman or mother, challenging the one-dimensional image of the all-sacrificing mother widely circulated in the literature and culture of Victorian England and revealing thereby how women remain "human" with all their "unnatural" cravings and are not subsumed into a single role. The paper will also try to place Hardy's eclectic and lenient attitude towards so-called maternal aberrations as a contrast to Victorian inflexibility with regard to gender roles.

Écrivain victorien incontesté de par la chronologie de sa vie et de son œuvre, Hardy se présente presque, dans son traitement des personnages féminins, comme féministe avant l'heure. Ses nouvelles s'offrent en contrepoint des romans dans leur représentation de figures de femmes et notamment de ces mères non mariées dont la maternité, évoquée dans toute sa complexité, vient occuper le centre de l'intrigue. Les personnages féminins se voient ainsi traités comme autant d'individualités, et non comme ces modèles types auxquels la société et la littérature victoriennes les réduisaient d'ordinaire. Pression sociale, inconfort physique et insatisfaction émotionnelle constituent les fondements de la victimisation d'une femme, et l'on peut difficilement attendre d'une femme ainsi victimisée qu'elle devienne une "bonne" mère, et d'autant moins une mère "parfaite". Cet article s'attache à étudier la façon dont certaines 
nouvelles de Hardy viennent semer le trouble dans la notion de femme ou de mère "parfaite", remettant en question l'image unidimensionnelle de la mère sacrificielle, largement répandue dans la littérature et la culture de l'Angleterre victorienne. On voit ainsi qu'en dépit d'instincts parfois jugés contre-nature, les femmes demeurent "humaines" et ne peuvent être réduites à un seul rôle. On essaiera également ici de placer l'indulgence du positionnement de Hardy vis-à-vis de ces prétendues aberrations maternelles en contraste avec l'intransigeance victorienne en matière de rôles genrés.

\section{INDEX}

Mots-clés: victorienne (époque), morale, femme, maternité, contre nature, genre, nouvelle Keywords: Victorian era, morals, women, motherhood, unnaturalness, gender, short story

\section{AUTHOR}

\section{OINDRILA GHOSH}

Dr Oindrila Ghosh is currently Assistant Professor in English, School of Humanities, Netaji Subhas Open University. Her PhD is on the treatment of motherhood in the short stories of Thomas Hardy. She has been a Charles Wallace India Trust UK, Scholar, 2009 and recipient of the Frank Pinion Award, 2014 from The Thomas Hardy Society, Dorset, UK. She has presented papers and published widely on Thomas Hardy in reputed international journals including The Victorian, Hardy Society Journal, The Thomas Hardy Journal and The Hardy Review and is also the only checklister from India for The Directory of Thomas Hardy's works for The Thomas Hardy Association, USA. She has also delivered several invited lectures on various aspects of Hardy's works in colleges and universities in her state. 